\title{
University Spin-Off: Effective Solution on Technology Transfer in AEC Industry for Intelligent City Transformation
}

\author{
Raihan MASKURIY ${ }^{1,2}$, Ali SELAMAT ${ }^{1}$, Kherun Nita ALI ${ }^{3}$, Akbariah MAHDZIR ${ }^{1}$, \\ Petra MAREŠOVÁ ${ }^{4}$ and Ondřej KREJCAR ${ }^{4 *}$ \\ 1 Universiti Teknologi Malaysia, Kuala Lumpur, Malaysia; raihan.maskuriy@gmail.com, aselamat@utm.my, \\ akbariah.kl@utm.my \\ 2 Universiti Putra Malaysia, Kuala Lumpur, Malaysia; raihanmaskuriy@upm.edu.my \\ 3 Universiti Teknologi Malaysia, Johor Bharu, Malaysia; b-kherun@utm.my \\ 4 Hradec Kralove University, Hradec Kralove, Czech Republic; petra.maresova@uhk.cz; ondrej.krejcar@uhk.cz \\ * Corresponding author: ondrej.krejcar@uhk.cz
}

\begin{abstract}
The growing use of Building Information Modelling (BIM) has had a positive impact on the Architecture, Engineering, and Construction (AEC) projects' implementation since the past few decades. On top of it, the arrival of Industry 4.0 has made a significant breakthrough by promoting digitalisation in the industry through BIM. However, this industrial transformation requires a lot of attention on the technology innovation process from technology development to technology adoption, where most innovations came from research in universities involving many disciplines. Collaboration between spin-off company with industry players acts as a natural Technology Transfer (TT) process able to exploit the research project before it goes into actualisation. This paper discusses a new way of collaboration between university and industrial players in order to achieve high level of innovation to give positive impact to the economy and social. This paper focusing on initial university-industry set up on the development of intelligent cities in Malaysia by 2040 using TT spin-off process and stage-gate innovation process.
\end{abstract}

Keywords: technology transfer; spin-off company; building information modelling; intelligent city; industry 4.0

JEL Classification: O30

\section{Introduction}

The Architecture, Engineering, and Construction (AEC) industry has experiencing an extraordinary rate of digital transformation due to the arrival of Building Information Modelling (BIM). For the past two decades, BIM provides faster development, reduced building costs, customer lifecycle management and eco-friendly business decisions throughout the construction life cycle (RIBA, 2013). The arrival of Industry 4.0 has introduced the AEC industry with digitalisation where BIM become the center of the development of powerful and innovative applications by extending the capability of BIM with the amalgamation of the disruptive technologies provided by industry 4.0 (Autodesk n.d.; Bilal et al., 2015). From smart design for virtual experience (Heidari et al., 2014), to smart 
construction to improve industrial process, quality and service (Štefanič \& Stankovski, 2019), to smart building to allow digital twin to facilitate the development of various smart applications (Chevallier et al., 2020), and to the development of smart city for sustainable and efficient living lifestyle, AEC industry has been taking advance innovation and social transformational steps to be an intelligence-enabled living lifestyle as an initiative to achieve sustainability and efficiency (Krejcar et al., 2019). However, to integrate such technologies and actualise it, many stakeholders and disciplines that cover multi-dimensions to complete the smart-things ecosystem need to be considered (Fernandez-Anez et al., 2018).

Research on disruptive technologies in AEC industry have been blooming though the stage of implementation is still infancy (Raihan Maskuriy et al., 2019) and literature continues to deliver high value outcome from the technologies to be utilised (Guerrero et al., 2019). University institutions have successfully driving TT to the industry players for commercialisation towards actualising the innovation of technology integration (Guerrero et al., 2019). Evidence says TT have a significant impact to the AEC market as it able to take large technological leap by investing on the technology from the institutes to gain new market and disrupt the current market and remain competitive (Uusitalo \& Lavikka 2020). To reach to this intensive TT and commercialisation, active role of scholars and scholarly and research institutions within academic entrepreneurship is necessary (Łącka, 2012). This spurred patenting and licensing activities from universities to allow intellectual property commercialisation where a university spin-off company acting as intermediaries between the university and other institutional spheres to bring forward their research to the industry (Clauss et al., 2018).

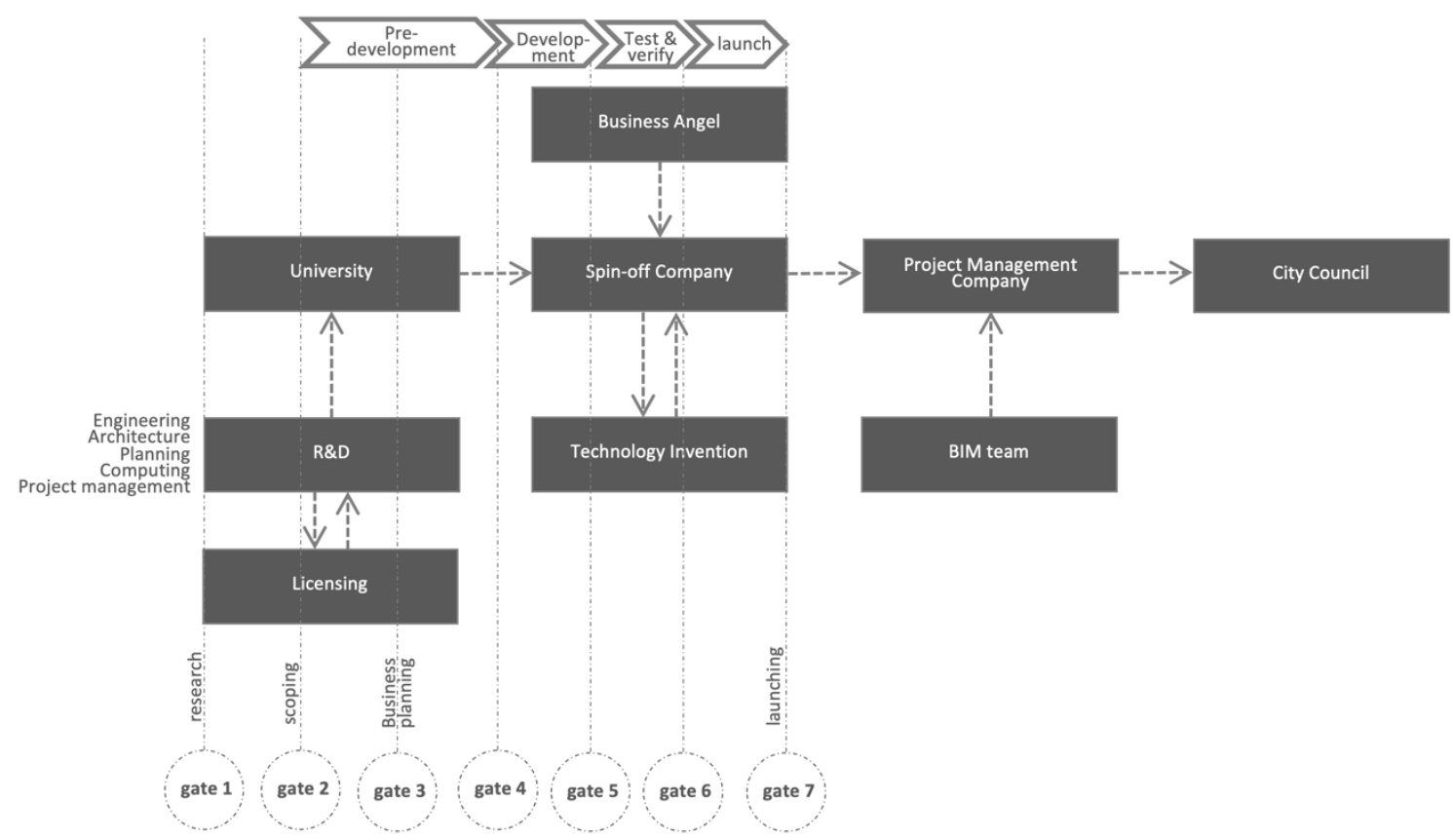

Figure 1. TT process of university spin-off in the development of intelligent city. (Adopted from Cooper, 1990 and Łącka, 2012) 
University spin-offs company refers to new firms created to exploit commercially viable knowledge, technology, or research outputs that were developed within a university which has the capacity to TT as the parent university act as the stakeholder (Jung \& Kim 2018). Research output that is marketable after receiving the licensing will be further developed by the spin-off company and will be going on test and verification stage to justify the workability of the technology. Adopted from TT spin-off process (Łącka, 2012) and stage-gate innovation process (Cooper, 1990), figure 1 shows the TT process of university spin-off where marketable research output will be further developed to contribute to the development of intelligent city.

In AEC industry during Industry 4.0 era, studies on the collaboration of BIM with technologies from Industry 4.0 to transform how the industry has been operating for decades, improving the quality and performance of the AEC industry. When study on BIM-based in industry 4.0 era is blooming in academic profession, collaboration between universityindustry on education has been flourishing in the literature. However, little evidence in the literature shows on BIM-based collaboration between university-industry for more industrial and commercialisation use. This paper would like to present a possible collaboration solution of TT using spin-off company as the intermediary entity to actualise a prospective marketable technology using the integration of BIM and sensor that could significantly contribute to the development of intelligent cities in Malaysia by 2040.

\section{Development of TT Spin-off}

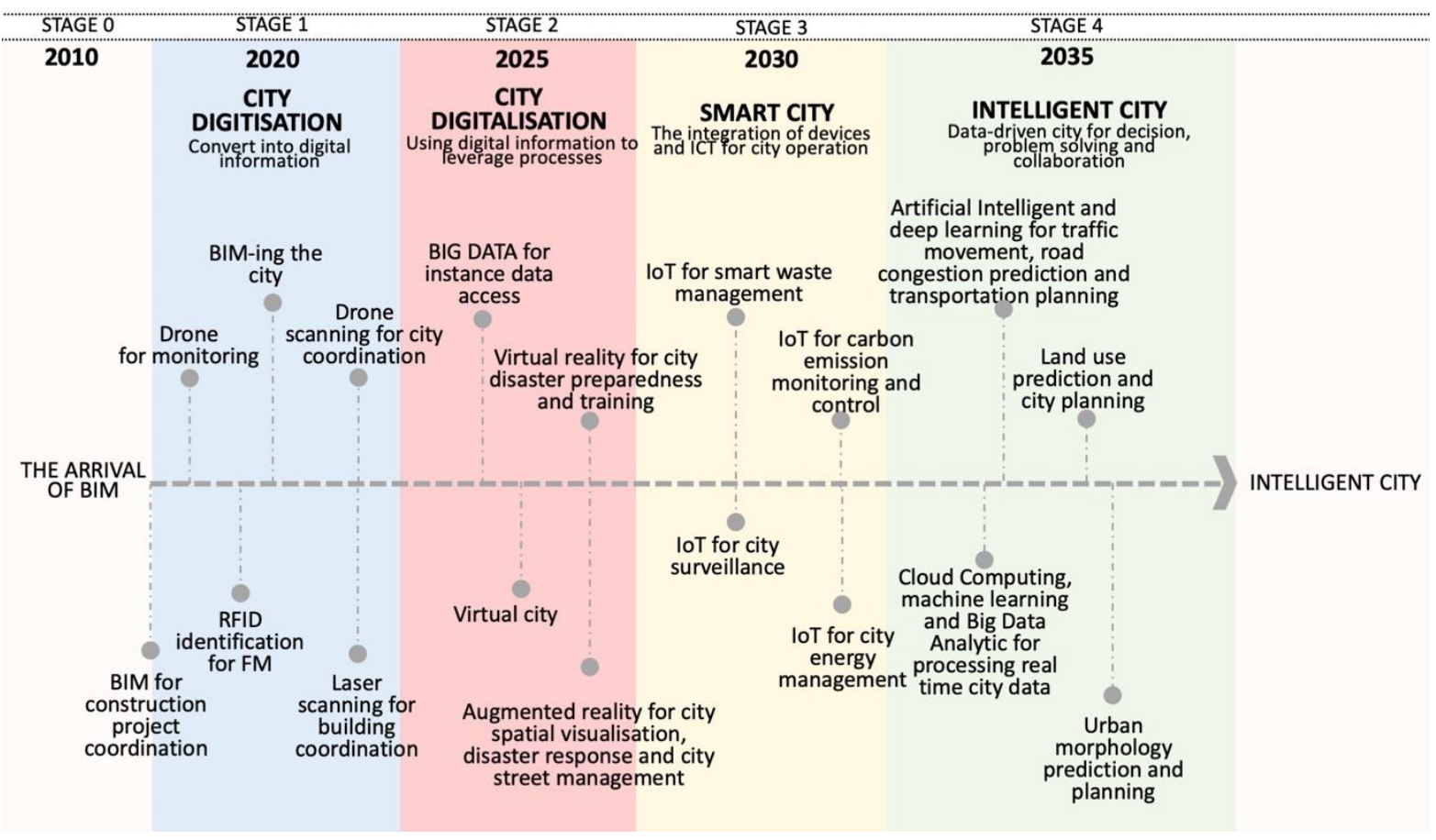

Figure 2. Initial intelligent city transformation roadmap

This paper is conceptualising the utilisation of TT spin-off process for the development of intelligent city in Malaysia. To actualising a BIM-based intelligent city is Malaysia, a collaboration between city council, industry players and universities is needed by proposing 
an intelligent city transformation roadmap before identifying potential technologies from research output to come up with commercialisation innovations that could benefit the development of intelligent city. The initial proposed intelligent city transformation roadmap is as illustrated in Figure 2.

The project started with the idea of digitising the city by the city council using BIM modelling with LoD 400 for full capacity operation. It is estimated that to digitise a $30 \mathrm{~km} 2$ city in two years with approximate 13,500 buildings require approximately 300 BIM staffs that run in two shifts a day all year around. If the project started in 2021, a complete digital city will be ready in 2023. After the city digitisation is completed, by taking the advantages of the BIM city model and leveraging the city process and upgrading the city lifesyle, the spin-offs are required to actualise technologies from research output to digitalise the digital city that can feed the needs of city based on the city council needs. Among the proposed technologies are Big Data city for instant data access, virtual city, virtual reality for city disaster preparedness and training, augmented reality for city spatial visualisation, disaster responses and city street management. This project is projected to be actualised by 2025 . The precedent case is Tokyo disaster simulation response that was proposed to demonstrate the disaster response to visitors for Tokyo Olympics 2020.

By 2030, the selected city is projected to be smarter by integrating the BIM-based city with smart devices and ICT for smart city operation. Among the technologies proposed are IoT for smart waste management, smart city surveillant, carbon emission monitoring and city energy management on top of other smart city technologies that do not required BIM-based city model. By 2035, the city is projected to be more intelligent by integrating the Artificial Intelligent, machine learning and deep learning for data driven insights for city intelligent decision planning. Among the technologies proposed are land use prediction and urban morphology for city planning, traffic movement, road congestion prediction and transportation planning.

\section{The Role of Actors in TT Spin-off for Intelligent City Transformation}

\subsection{Role of Researcher}

Researchers' task is to develop new technologies that are needed for future needs of the intelligent city transformation. The current targeted research is BIM-based smart energy monitoring and smart construction waste management. For BIM energy management, researchers created BIM model for smart indoor temperature monitoring using a BIM authoring application, and sensors devices are installed to collect environment data. Autodesk Revit is used to create the BIM model of an existing building in the experiment. A mini Weather Station in the room using Arduino microcontrollers and Raspberry Pi was built. The sensor readings are then automatically stored in the BIM model. In order to store sensor readings in the model, a software application is developed using Dynamo, which is a visual programming environment for Revit. The sensor reading will be appeared in the BIM model to monitor the environment in the room for smart building program (Figure 5). The system will be further undergoing experiments in few buildings for city energy monitoring. 


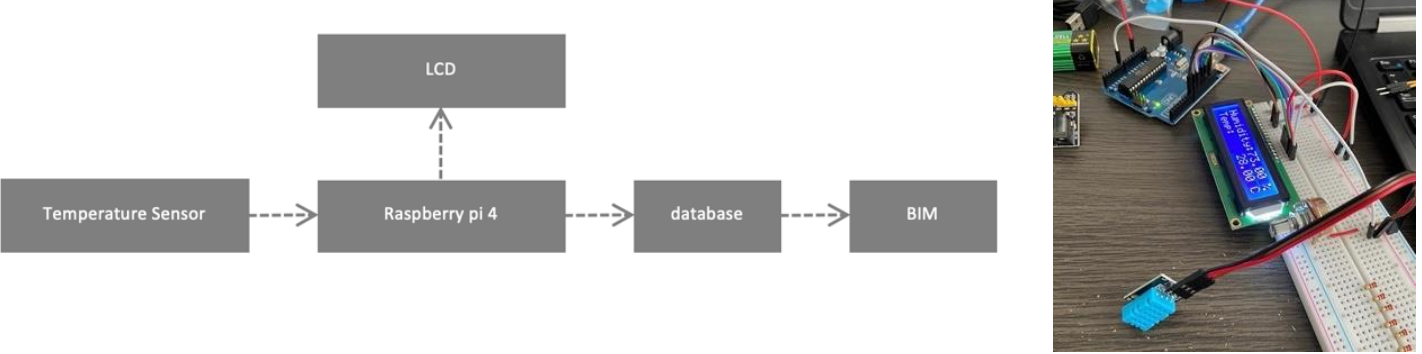

Figure 5: BIM-based smart energy monitoring

For smart construction waste management, during the waste production (construction stage), IoT application able to optimise the use of BIM. It increases the productivity by improving the waste management operations. It extends the BIM capabilities by monitoring the material handling on site, segregates the waste on site, monitors the operation of the project, and supervises the workers using the BIM model. This process could be done when the IoT Waste Analysis is coordinated with the BIM Waste Analysis. The innovation of IoT application also able to be extended to track down the routes, location of the truck, and the amount of waste carried by the trucks. This enhances the operation and data management for third party use such as local authorities, government agencies and waste collectors. From the IoT Waste Analysis, the recorded data able to be channelled out to the construction waste solution to project for new material value chain.

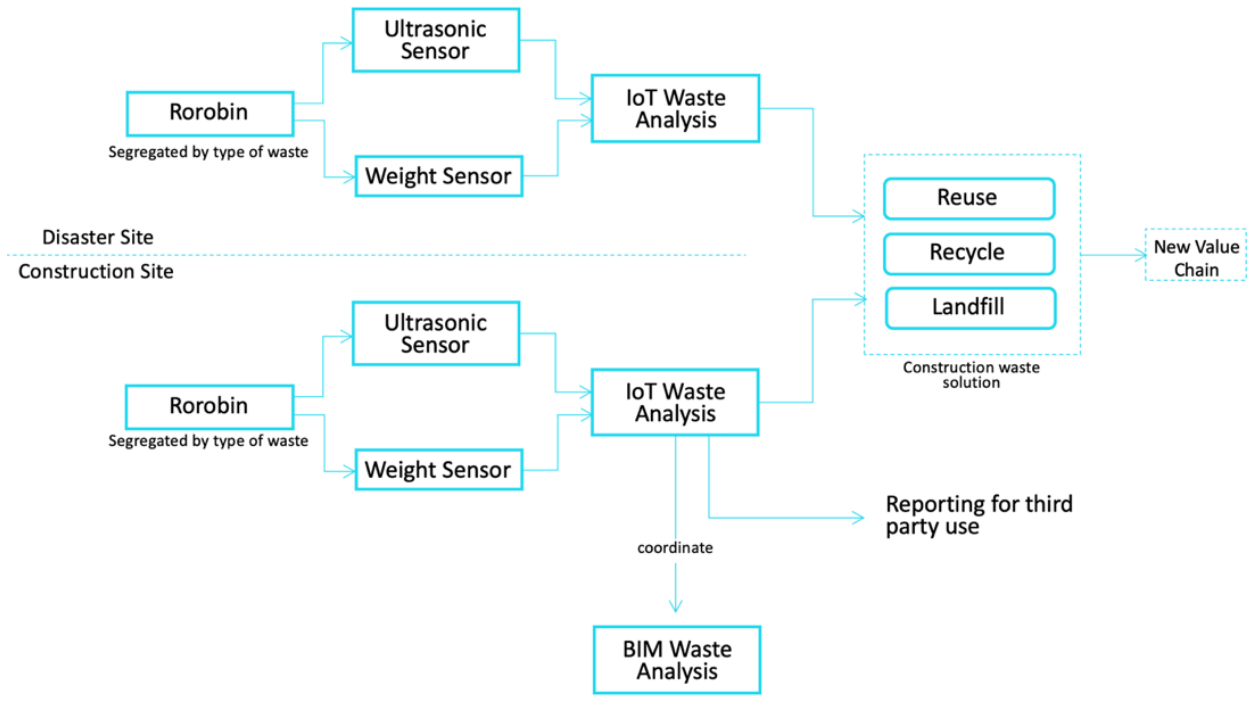

Figure 6: Waste Analysis Strategy at Waste Production Stage. (Maskuriy et al., 2020)

\subsection{Role of University Spin-off}

The university spin-off company task are 1) to do the screening of the proposed technology for BIM-based smart energy management and smart construction waste management that derived from the research according to the client's needs and academic study; 2) to do prototyping and refinement of the technology for commercial purposes, 3) to make the business plan real, 4) to propose extensive angel funding mechanisms, and 5) to 
network by doing industry linkages session with industry players to actualising the technology.

\subsection{Role of Project Management Company}

The project management company task are 1) to do pitching business presentation to the city council regarding the proposed technologies for the intelligent city, 2) develop clear, straightforward plans to reach full potential of the project, 3) program the action planning schedule, 4) estimate a projection cost, and 5) monitor and managing the project including the risk.

\subsection{Role of BIM Team}

BIM team are divided into three departments - BIM management team, BIM coordination team and BIM modelling team. As of now, these departments are required to do 1) architectural, structural, mechanical and electrical BIM model, 2) review the quality and issues of the models, 3) report and document to project management company. These tasks are only covering the digitisation stage. The task will be revised after spin-off company come out with new BIM-based innovation technology and BIM team will requires extensive training to integrate BIM technology with technology from industry 4.0.

\section{Discussion}

Malaysia has spent huge amount to R\&D, however the innovation produced are much fewer than other country that spent lesser as lacking of exposure to the advantages of IP rights and the commercial value of patenting local research output are dominating the research industry (Kaur 2019). Spin-off is an excellent solution to TT to the industry for innovation and commercialisation especially in AEC industry for intelligent city transformation. TT is known as an approach that favoured by developed country like Germany and Korea to successfully innovate and commercialise their product and changeover to Industry 4.0 (Gausemeier et al. 2016; Jung \& Kim 2018). While spin-off acts as centre mechanism that add values to the research output by ensuring the viability of the product or service through the innovation of technologies after go through series of screening, scoping, development, testing and verifying.

In Malaysia, the development of smart city has been initiated in the Twelve Malaysia Plan as an initiative to transform the city in Malaysia into a vibrant and prosperous metropolitan area. To move forward toward more intelligent, government agencies, universities and industry players must joint force to actualise the ideas that have been initiated in the research from universities, research institutes and centre of excellent in Malaysia. The milestone program has been outlined according to the fit of the technology adoption strategy based on TT approach through the university spin-off company. This approach able leverage the knowledge that previously stays in as a research output and provide added value for the industry with a commercially valuable innovation in research output. 
For Malaysia able to adopt TT spin-off approach, universities must break the shell and work together with the industries and government agencies. University spin-offs needs to do more screening for more potential technologies that can be actualised to pace up with the development of intelligent city. More IPs should be developed and commercialised locally for the investment to R\&D would not be in vain. Malaysia should follow other developed country where their IPs have spurred their country's economic growth.

Acknowledgments: This study would like to thank you to ViewDepth Resources for generous information and contribution to the research project.

\section{References}

Autodesk. "BIM 360 API." : 1-4. https://forge.autodesk.com/en/docs/bim360/v1/overview/introduction/ (May 1, 2019).

Bilal, M., et al. (2015). Analysis of Critical Features and Evaluation of BIM Software: Towards a Plug-in for Construction Waste Minimization Using Big Data. International Journal of Sustainable Building Technology and Urban Development 6(4), 211-228. https://doi.org/10.1080/2093761X.2015.1116415

Chevallier, Z., Finance, B., \& Boulakia, B. C. (2020). A Reference Architecture for Smart Building Digital Twin. In CEUR Workshop Proceedings (vol. 2615, pp. 1-12).

Clauss, T., Moussa A., \& Kesting, T. (2018). Entrepreneurial University: A Stakeholder-Based Conceptualisation of the Current State and an Agenda for Future Research. International Journal of Technology Management 77(1-3), 109-44. https://doi.org/10.1504/IJTM.2018.091726

Cooper, R. G. (1990). Stage-Gate Systems: A New Tool for Managing New Products. Business Horizons.

Fernandez-Anez, V., Fernández-Güell, J. M., \& Giffinger, R. (2018). Smart City Implementation and Discourses: An Integrated Conceptual Model. The Case of Vienna. Cities, 78(August), 4-16. https://doi.org/10.1016/j.cities.2017.12.004

Gausemeier, J., et al. (2016). On the Road To Industry 4.0: Technology Transfer in the SME Sector. It's OWL Clustermanagement GmBH (pp. 1-32). https://www.itsowl.com/fileadmin/PDF/Informationsmaterialien/2017-Technology_Transfer_web.pdf.

Guerrero, M., Urbano, D., \& Herrera, F. (2019). Innovation Practices in Emerging Economies: Do University Partnerships Matter? Journal of Technology Transfer, 44, 615-646. https://doi.org/10.1007/s10961-017-9578-8

Heidari, M., et al. (2014). Smart-BIM Virtual Prototype Implementation. Automation in Construction, 39, $134-144$. https://doi.org/10.1016/j.autcon.2013.07.004

Jung, H., \& Kim, B. K. (2018). Determinant Factors of University Spin-off: The Case of Korea. Journal of Technology Transfer, 43(6), 1631-1646. https://doi.org/10.1007/s10961-017-9571-2

Kaur, M. (2019, May 16). Malaysia's RED Spending More than Finland's, but Is It Worth It, Asks Think Tank. Retrieved from https://www.freemalaysiatoday.com/category/nation/2019/05/16/malaysias-rd-spendingmore-than-finlands-but-is-it-worth-it-asks-think-tank/

Krejcar, O., Maresova, P., Selamat, A., Melero, F. J., Barakovic, S., Husic, J. B., Herrera-Viedma, E., Frischer, R., \& Kuca, K. (2019). Smart Furniture as a Component of a Smart City - Definition Based on Key Technologies Specification. IEEE Access, 7, 94822-94839. https://doi.org/10.1109/ACCESS.2019.2927778

Łącka, I. (2012). The Role of Academic Entrepreneurship and Spin-Off Companies in the Process of Technology Transfer and Commercialisation. Journal of Entrepreneurship, Management and Innovation, 8(1), 68-83.

Maskuriy, R., et al. (2020). Manmade Disaster Prevention Using Waste Management Hierarchy and Disaster Management Cycle. In IOP Conference Series Earth and Environmental Science.

Maskuriy, R., Selamat, A., Ali, K. N., Maresova, P., \& Krejcar, O. (2019). Industry 4.0 for the Construction Industry-How Ready Is the Industry? Applied Sciences, 9(14), 2819. https://doi.org/10.3390/app9142819

RIBA. (2013). RIBA Plan of Work 2013: Overview.

Štefanič, M., \& Stankovski, V. (2019). A Review of Technologies and Applications for Smart Construction. Proceedings of the Institution of Civil Engineers - Civil Engineering, 172(2), 83-87. https://doi.org/10.1680/jcien.17.00050

Uusitalo, P., \& Lavikka, R. (2020). Technology Transfer in the Construction Industry. Journal of Technology Transfer (0123456789). https://doi.org/10.1007/s10961-020-09820-7. 